\title{
Effect of Methyl Jasmonate and Mannitol Application on Growth and Eugenol Content in Callus Cultures of Carnation
}

\author{
Mohamed A. Matter, Moemen S. Hanafy and Usama I. Aly* \\ Plant Biotechnology Department, Genetic Engineering and Biotechnology Division, \\ National Research Center, 33 El Behouth Street, Dokki, Giza, Egypt
}

Key words: Dianthus caryophyllus, Methyl Jasmonate, Mannitol, Eugenol, HPLC

\begin{abstract}
A protocol for callus induction from leaves of carnation is established. MS fortified with $2.0 \mathrm{mg} / 12,4-\mathrm{D}$ and $0.5 \mathrm{mg} / \mathrm{Kn}$ was found to be the appropriate medium for producing callus cultures. Methyl jasmonate at $20 \mu \mathrm{M}$ concentration showed the highest growth rate $(98.21 \mathrm{mg} /$ day $)$ while mannitol concentrations at $2 \%$ gave the peak growth rate $(97.1 \mathrm{mg} /$ day).The highest content of eugenol $(14.65 \mu \mathrm{g} / 100 \mathrm{~g}$ calli) was recorded with medium containing $20 \mu \mathrm{M}$ methyl jasmonate followed by $8.16 \mu \mathrm{g} / 100 \mathrm{~g}$ calli with $10 \mu \mathrm{M}$ methyl jasmonate. In presence of $0.5 \%$ mannitol, maximum eugenol content $(18.00 \mu \mathrm{g} / 100 \mathrm{~g}$ calli) was obtained.
\end{abstract}

\section{Introduction}

The carnation (Dianthus caryophyllus L.) is an important cut flower crop of the Caryophyllaceae family. Cuttings of $D$. caryophyllus have a sizeable division of the world's cut flower production market and progressively moved up ( $\mathrm{Lu}$ et al. 1991, Jurgens et al. 2003). Large scale plantation and international trade were mainly take place in Latin America, Europe, a few Asian, some African and Mediterranean countries (Sparnaaij 1987, Zuker et al. 2002). Carnation has been considered in European traditional herbal medicine to treat coronary and nervous disorders (Chevallier 1996). It is an aromatic, stimulant plant that has been used in tonic cordials to treat fevers, though this use is now old-fashioned (Bown 1995). Moreover, the flowers were believed to be alexiteric, antispasmodic, cardiotonic, and diaphoretic and used as a vermifuge (Chopra et al. 1986).

*Authors for correspondence: <usamajp@yahoo.com>. 
From the middle of last century, scientists were exerting their efforts to cultivate carnation plants using cell culture systems (Esmaiel et al. 2013). A callus culture of carnation was established by many researchers (Buiatti et al. 1985, Palet et al. 1991, Zuker et al. 2002). The major importance of carnation remains with the cut flower market. Client preference concerning coloring and growth uniqueness is mandatory for breeders to release new cultivars (Lu et al. 1991). ElGhorab et al. (2006) affirmed that, about 12 volatiles were identified as the main components of carnation flower fragrance signature. Clery et al. (1999) reported that, flowering carnations aroma volatiles were differentiated by the fraction of eugenol (trace- $84.1 \%$ ) and methyl salicylate $(0.1-1.4 \%)$.

Carnation essential oils obtained from the flowers are used in perfumery (Uphof 1968). The flower heads are dried and used in potpourri, scented sachets and cosmetic products (Bown 1995). The leaves can be simmered in water, and this water can then be used as soap for cleaning the skin, clothes, etc. (Allardice 1993).The plant also has antifungal activity due to the presence of flavonoid glycosides (Galeotti et al. 2008).

To supply the market demands and industries requirements it is necessary to maintain a constant essential oil production and quality, mainly in terms of chemical composition (Silva 2002). The essential oil production does not depend only on plant genetics or developmental stage. The environment and its changes can influence in a significant way biochemical pathways and physiological processes that alter plant metabolism and, therefore, the essential oil biosynthesis (Sangwan et al. 2001).

Since 1940 natural and synthetic growth regulators have been used in agriculture to control developmental processes like germination, vegetative growth, reproduction, maturation, senescence and post harvest (Basra 2000). The use of growth regulators in agricultural production has increased due to their positive influence on product quality. This is a common practice in small countries where this technology is necessary to achieve higher yields and better products (Poyh and Ono 2006). It is known that plant growth and development are regulated by action and balance of different groups of growth regulators, which promote or inhibit such processes. Nevertheless, the effects of the use of plant growth regulators on essential oil production are not well known (Ortuño et al. 1999, Poyh and Ono 2006).

Mannitol is a six carbon sugar alcohol which commonly used in plant cell culture as an osmoprotectant and is believed to be metabolically inert because it is very slowly taken up by a wide range of plant cells (Thimann et al. 1960, Yuri 1988, Nade1 et al. 1989). Besides its function in osmotic adjustment, mannitol improves tolerance to stress through scavenging of hydroxyl radicals and 
stabilization of macromolecular structures (Crowe et al. 1992, Shen et al. 1997). The importance of mannitol as a scavenger of the hydroxyl radical has been demonstrated in vitro (Smirnoff and Cumbes 1989) and in vivo using transgenic tobacco (Shen et al. 1997).

The accumulation of metabolites often occurs in plants subjected to stress, due to various elicitors or signal molecules (Zhao et al. 2005). The jasmonates are possibly signal compounds in the elicitation process inducing transcriptional activation of genes involved in de novo formation of secondary metabolites (Zhang and Memelink 2009). For this reason, elicitation has been used to increase the accumulation of active metabolite in plant tissue and cell cultures (Matkowski 2008).

There remains a need to increase secondary metabolite production rates to support their commercial exploitation. To overcome the present limitations, one approach is elicitation. The elicitor molecule interacts with a plant membrane receptor (Cosio et al. 1990) that through an unidentified mechanism activates specific genes (Menke et al. 1999), resulting in the synthesis of almost all chemical classes of secondary plant products (Zhao et al. 2001).

Among the various elicitors, exogenous methyl jasmonate (MJ) has been confirmed as effective for the induction of secondary metabolites in plant cell cultures (Ketchum et al. 1999). It has also been established that treatments with exogenous MJ can elicit the accumulation of several classes of alkaloids, including the benzophenanthridines (Gundlach et al. 1993), the vinca alkaloids (Aerts et al. 1996) and the tropane alkaloids (Saenz-Carbonell et al. 1996), in a range of plant species. Jasmonic acid (JA) and MJ are considered to be involved in a part of the signal transduction pathway that induces particular enzymes to catalyze biochemical reactions to form defense compounds of low molecular weight in plants, such as polyphenols, alkaloids, quinones, terpenoids, and polypeptides (William et al. 1996, Mizukami et al. 1993).

The aim of this paper is to study the effect of different concentrations of methyl jasmonate and mannitol on growth rate and eugenol content of Dianthus caryophyllus callus cultures.

\section{Materials and Methods}

Under sterile conditions, seeds of Dianthus caryophyllus were surface sterilized by immersion in $70 \%$ ethanol for $10 \mathrm{sec}$, followed by rinsing three times in sterile distilled water. Seeds were then immersed in different concentrations of commercial Clorox solution (contain 5.25\% sodium hypochlorite) 15 and $25 \%$ for different periods 15 and $25 \mathrm{~min}$ and rinsed three times 
with sterile distilled water. The disinfected seeds will then placed on $200 \mathrm{ml}$ glass jars containing $50 \mathrm{ml}$ of solidified basal MS. Culture medium was solidified by 7 $\mathrm{g}$ agar, adjusted at $\mathrm{pH}$ 5.8. Cultures were incubated in a growth chamber at 25 $\pm 2^{\circ} \mathrm{C}$ under light conditions of $16 \mathrm{hr}$ day photoperiod at intensity of $2000 \mathrm{Lux}$ from cool white fluorescent lamps. Within four weeks of cultivation, the in vitro growing plantlets attained about $6-8 \mathrm{~cm}$ in height and used as starting plant material.

Leaf segments $\left(0.3 \mathrm{~cm}^{2}\right)$ were excised from in vitro growing plantlets and cultured on MS supplemented with $0.0,0.5,1.0$ or $2.0 \mathrm{mg} / 1$ 2,4-D in combination with 0.0, 0.5, 1.0 or $2.0 \mathrm{mg} / \mathrm{l} \mathrm{Kn}$ (Sigma Chemical Company St. Louis , Mo 63178 USA ) as shown in Table 1. Cultures were incubated in a growth chamber at $25 \pm$ $2^{\circ} \mathrm{C}$ under light conditions of $16 \mathrm{hrs}$ day photoperiod intensity of 2000 lux from cool white fluorescent lamps. After four weeks of cultivation, the culture media were evaluated to point the optimal medium introducing callus.

This experiment was carried out to study the effect of methyl jasmonate $\left(\mathrm{C}_{13} \mathrm{H}_{20} \mathrm{O}_{3}\right)$ on growth and eugenol content in extracted essential oils. Calli (200 $\mathrm{mg}$ ) were subcultured onto MS supplemented with different concentrations (0.0, 10.0, 20.0, 30.0 and $40.0 \mu \mathrm{M}$ ) of methyl jasmonate, (Sigma chemical company St. Louis, Mo 63178 USA). The culture media contained $2.0 \mathrm{mg} / 1$ 2, 4-D and $0.5 \mathrm{mg} / \mathrm{l}$ $\mathrm{Kn}$ as the optimal concentration obtained before. Cultures were incubated in a growth chamber at $25 \pm 2{ }^{\circ} \mathrm{C}$ under light condition $16 \mathrm{hrs}$ day photoperiod at intensity of 2000 lux from cool white fluorescent lamps. Data of growth dynamics and quantitative analysis of the eugenol in essential oils were recorded.

Effect of mannitol $\left(\mathrm{C}_{6} \mathrm{H}_{14} \mathrm{O}_{6}\right)$ as osmotic stress on growth and eugenol content in extracted essential oils in calli cultures was studied. Calli $(200 \mathrm{mg})$ were transferred to MS supplemented with different concentrations (0.0, 0.5, 1.0 and $2.0 \%$ ) of mannitol (Sigma chemical company St. Louis, Mo 63178 USA) in presence of growth regulators 2,4-D (2.0 mg/l) and $\mathrm{Kn}(0.5 \mathrm{mg} / \mathrm{l})$. Cultures were incubated as previously described for four weeks.

The growth of calli cultures was monitored by weekly measurement of average fresh weight $(\mathrm{mg})$. Growth rate (mg fw/day) was determined according to Szoke et al. (1979) as follows:

Growth rate $=\mathrm{G}_{\mathrm{e}}-\mathrm{G}_{\mathrm{s}} / 7$

where: $G_{e}=$ Callus mass (mg) at the end of every week and $G_{s}=$ The starting mass (mg) of callus.

Essential oil content of each treatment was extracted with hydro-distillation by adding water to the tissue material and boiling the mixture for $3 \mathrm{hrs}$ at Clevenger-type apparatus using fresh calli according to Guenther (1961). The 
resulted essential oil of each treatment was separately dehydrated with anhydrous sodium sulphate and kept in the deep freezer until used for biological activity.

The HPLC system used for quantification of eugenol according to the method of Saran et al. 2013, consisted of a Jasco PU-980 pump, AS-2057 auto sampler and Jasco UV-970 detector. The chromatogram peaks were quantified by means of PC based Borwin software (Version 1.5). Chromatography separation for analyte was achieved on cosmosil $C_{18}$ analytical column $(150 \mathrm{~mm} \times 4.6 \mathrm{~mm} 5 \mu)$ maintained at ambient temperature. The mobile phase was pumped at flow rate $1 \mathrm{ml} / \mathrm{min}$. The mobile phase was filtered through a $0.45 \mu$ nylon membrane filter and degassed in an ultrasonic bath prior to use. The injection volume was $30 \mu \mathrm{l}$, the flow rate was $1.0 \mathrm{ml} / \mathrm{min}$ and chromatographic peak was detected at $215 \mathrm{~nm}$. The results presented are the mean values \pm standard deviation (Sd) obtained from at least three replicates (Snedecor and Cochran 1980).

\section{Results and Discussion}

To provide the necessary plant materials for callus induction, disinfection of Dianthus caryophyllus seed surfaces with Clorox (5.25\% NaOCl) took place at $25 \%$ concentration for $25 \mathrm{~min}$. Surface-sterilized seeds were aseptically germinated on basal MS. Seeds started germination within two weeks of cultivation, and reached $95 \%$ after one month cultivation (Fig. 1).

Different concentrations of 2, 4-D and Kn were examined. Leaf explants excised from in vitro growing plantlets were cultured on solid MS supplemented with 2, 4-D (0.0. 0.5, 1.0 and $2.0 \mathrm{mg} / \mathrm{l})$ and $\mathrm{Kn}(0.0,0.5,1.0$ and $2.0 \mathrm{mg} / \mathrm{l})$. Callus initiation was observed within two weeks of cultivation.

Calli derived from the different treatments were evaluated depending on their fresh weight after four weeks of cultivation. Data clearly revealed the significance of 2,4-D for callus induction even when Kn was added to culture media (Table 1).

Based on fresh weight measurements, solid MS with $2.0 \mathrm{mg} / \mathrm{l} 2,4-\mathrm{D}+0.5 \mathrm{mg} / \mathrm{l}$ $\mathrm{Kn}$ was the most appropriate medium for callus initiation (2174.6 mgfw), followed by MS + $2.0 \mathrm{mg} / 1$ 2,4-D + $1.0 \mathrm{mg} / \mathrm{l} \mathrm{Kn}$ (2086 mgfw) (Table 1).

Growth dynamics of calli cultures were done in order to point out the optimal time for transferring calli into fresh culture medium, when calli reached its maximum fresh weight. Each treatment was started with initial weight $(200 \mathrm{mg})$ of callus and cultured on the selected medium for callus production $(2.0 \mathrm{mg} / \mathrm{l}$ 2, 4-D and $0.5 \mathrm{mg} / \mathrm{l} \mathrm{Kn}$ ). 
Table 1. Fresh weight of leaf derived calli of Dianthus caryophyllus after four weeks of cultivation on MS supplemented with different combinations of 2,4-D and $\mathrm{Kn}$. Values are the mean of 3 replicates.

\begin{tabular}{ccc}
\hline \multicolumn{2}{c}{ Growth regulators $(\mathrm{mg} / \mathrm{l})$} & \multirow{2}{*}{ Mean fresh weight } \\
\cline { 1 - 2 } $2,4-\mathrm{D}$ & $\mathrm{Kn}$ & 0.0 \\
0.0 & 0.5 & 0.0 \\
0.0 & 1.0 & 0.0 \\
0.0 & 2.0 & 250.0 \\
0.5 & 0.5 & 0.0 \\
0.5 & 1.0 & 0.0 \\
0.5 & 2.0 & 610.0 \\
1.0 & 0.5 & 0.0 \\
1.0 & 1.0 & 0.0 \\
1.0 & 2.0 & 2174.6 \\
2.0 & 0.5 & 2086 \\
2.0 & 1.0 & 470.0 \\
2.0 & 2.0 & \\
\hline
\end{tabular}
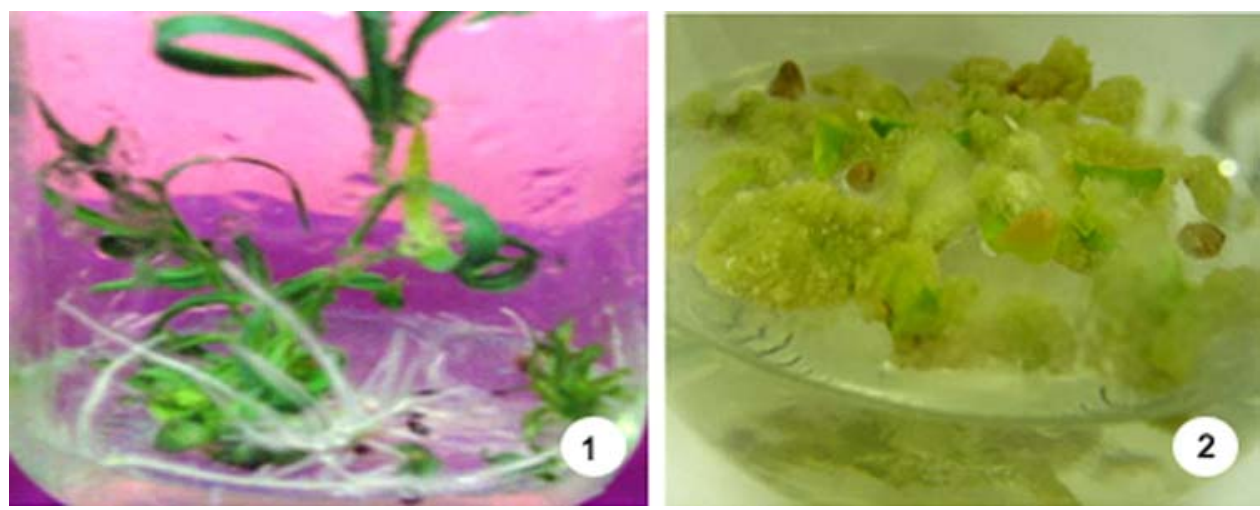

Figs 1-2. 1. Seedling germination of Dianthus caryophyllus after one month cultivation on MS. 2. Callus derived from leaf explants of Dianthus caryophyllus cultured on MS supplemented with $2.0 \mathrm{mg} / \mathrm{l}$ 2, 4-D and $0.5 \mathrm{mg} / \mathrm{K} \mathrm{Kn}$.

Data presented in Fig. 3 indicated that calli fresh weights were gradually increased during the culture period until the fourth week, and declined at the fifth week. The fresh weight reached its maximum $(2174.6 \mathrm{mg})$ at the fourth week. Likewise, the growth rate took a trend like those observed in fresh weight (Fig. 3). The growth rates were progressively increased and reach its maximum (282 mg/day) at the fourth week before slowly turned down (Fig. 3).

The results indicated that MS supplemented with $\mathrm{Kn}$ as a sole growth regulator did not stimulate callus induction except with $0.5 \mathrm{mg} / 1$ 2, 4-D. The 
same result was obtained in the presence of 2, 4-D and $\mathrm{Kn}$ in equal concentrations, and in the presence of higher concentration of Kn than 2, 4-D. Callus induction from leaf explants was achieved with $2.0 \mathrm{mg} / \mathrm{l}$ 2, 4-D and 0.5 $\mathrm{mg} / \mathrm{l} \mathrm{Kn}$. In vitro culture of carnation has been reported (Miller et al. 1991, Nugent et al. 1991). Major emphasis in D. caryophyllus studies was paid attentions for cultivar, explants, growth regulators and medium formulations (Mii et al. 1990). The obtained results were in agreement with those of Rao et al. (1997). They reported that callus tissues were induced from the leaf explants of clove when cultured on MS comprised $2.0 \mathrm{mg} / 1$ 2, 4-D and $0.5 \mathrm{mg} / 1 \mathrm{Kn}$.

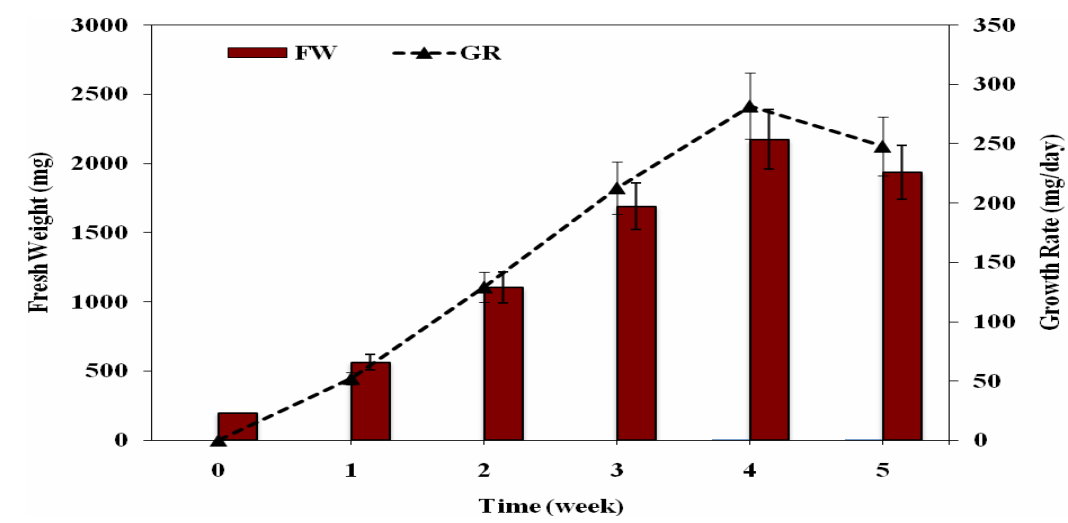

Fig. 3. Effect of cultivation time on fresh weight and growth rate of Dianthus caryophyllus callus cultured on MS supplemented with $2.0 \mathrm{mg} / 1$ 2,4-D and $0.5 \mathrm{mg} / \mathrm{l} \mathrm{Kn}$. Values are the mean of 3 replicates $\pm S d$.

In vitro callus induction requires a change in cell metabolism from a quiescent state to one of active cell divisions, which often means the reversal of cell differentiation and specialization. Auxin is normally required in the medium to induce callus from explants, the most common being 2,4-D (Phillips 2004). It is well known that callus formation is a result of cell division and cell enlargement as well as auxins increase cell growth, while cytokinins stimulate cell division (Gamborg and Shyluk 1981). The synthetic auxins (2,4-D) are used more commonly in tissue culture, depending on the plant species to be cultured (Laiu and Boll 1970). The most potent auxin, 2, 4-D, may be used in the range of 0.1$10.0 \mathrm{mg} / \mathrm{l}$ (Mantell and Smith 1989). The effective role of 2, 4-D in callus production from Kidney bean was reported by Laiu and Boll (1970) who obtained callus from different explants on culture medium containing $2 \mathrm{mg} / \mathrm{l}$ 2, 4-D plus $0.64 \mathrm{mg} / \mathrm{l} \mathrm{Kn}$. On the other hand, Griga and Klenoticova (1994) found that 2, 4-D is essential for callus establishment from faba bean. 
The effect of methyl jasmonate $\left(\mathrm{C}_{13} \mathrm{H}_{20} \mathrm{O}_{3}\right)$ on leaf callus growth. Callus tissues (200 $\mathrm{mg}$ ) were sub-cultured onto MS supplemented with different concentrations $(0.0,10.0,20.030 .0$ and $40.0 \mu \mathrm{M})$ of methyl jasmonate. The selected culture media contained $2.0 \mathrm{mg} / 1$ 2, 4-D and $0.5 \mathrm{mg} / \mathrm{l} \mathrm{Kn}$. Fresh weight of three replicates was recorded every week to calculate the growth rate. The calli were collected for essential oil extraction and analyzed using HPLC. Fig. 4 showed that the highest growth rate was recorded on medium containing $20 \mu \mathrm{M}$ of methyl jasmonate ( $98.2 \mathrm{mg} /$ day). It was clear that the presence of MJ at different concentrations escalating the growth rate compared to control medium (Fig. 4).

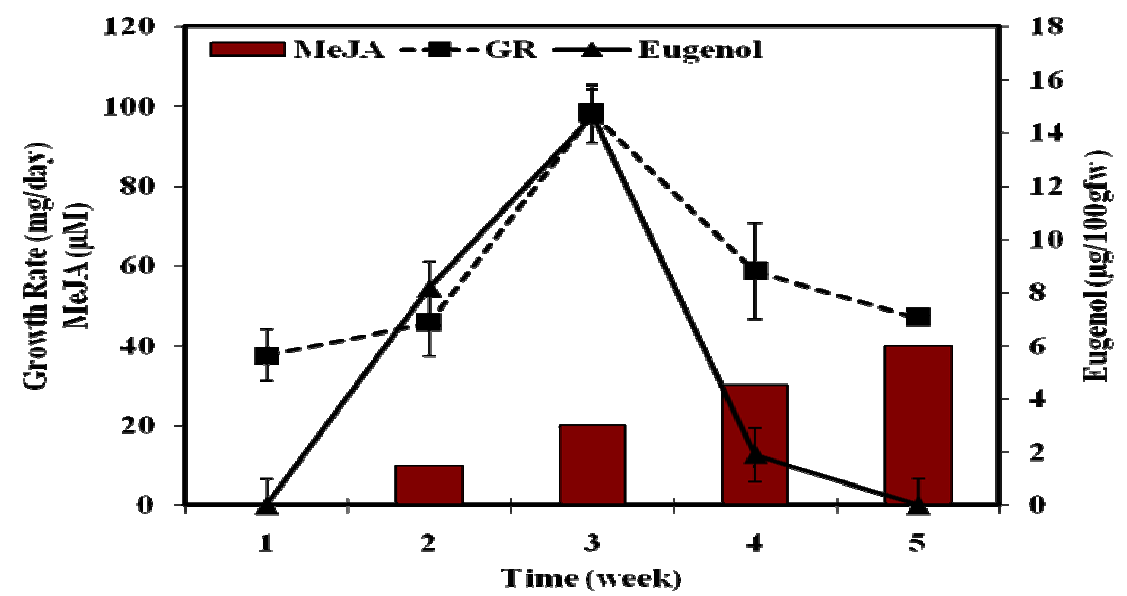

Fig. 4. Effect of different concentrations of methyl jasmonate on growth rate and eugenol content of Dianthus caryophyllus callus cultured on MS supplemented with $2.0 \mathrm{mg} / \mathrm{l}$ 2,4-D and $0.5 \mathrm{mg} / \mathrm{K} \mathrm{Kn}$. Values are the mean of 3 replicates $\pm \mathrm{Sd}$.

For eugenol content, data presented in Fig. 4 showed that the highest content of eugenol $(14.65 \mu \mathrm{g} / 100 \mathrm{~g}$ calli) was recorded with medium containing $20 \mu \mathrm{M}$ methyl jasmonate followed by $8.16 \mu \mathrm{g} / 100 \mathrm{~g}$ calli in medium with $10 \mu \mathrm{M}$ methyl jasmonate. On the other hand, the lowest content of eugenol $(1.89 \mu \mathrm{g} / 100 \mathrm{~g}$ calli) was recorded in medium containing $30 \mu \mathrm{M}$ of methyl jasmonate. In control medium and that containing $40 \mu \mathrm{M}$ of methyl jasmonate there were no detectable amount of eugenol.

Essential oils are the most important raw materials of the fragrance and aroma industry. They are also used in the food and pharmaceutical industries due to their therapeutic, antimicrobial and antioxidant activities. Nevertheless, they have biological activities that make them suitable for use as herbicides, pesticides and anticancer compounds (Mahmoud and Croteau 2002, Burfield and Reekie 2005). 
Endogenous factors like development stage of whole plant and specific organs, and exogenous factors (biotic and abiotic) can alter essential oil production (Sangwan et al. 2001, Lima et al. 2003, Gobbo-Neto and Lopes 2007). Methyl jasmonate (MeJA) has been reported to play an important role in the signal transduction process that regulates defense genes in plants (Gundlach et al. 1993). The present results were moderately agreed with those obtained by Rebecca and Deepa (2012) who evaluated the effect of methyl jasmonate on cell cultures of sweet basil. They found that methyl jasmonate was found to strongly affect cell growth; $25 \mu \mathrm{M}$ of MeJA were found to accumulate highest biomass for $O$. basilicum and $O$. sanctum, and $50 \mu \mathrm{M}$ for $O$. gratissimum. This study demonstrates that elicitors such as methyl jasmonate could effectively enhance cell biomass and hence can be used for effective induction of phytochemicals. Also our results were concomitant with those obtained by Kim et al. 2006. They found that rosmarinic acid and caffeic acid content of sweet basil was significantly increased with MeJA application compared to control. Furthermore, eugenol was increased by $56 \%$, by $0.5 \mathrm{mM}$ MeJA treatment.

The effect of mannitol as osmotic stress mediator on callus growth and eugenol content in extracted essential oils were studied. Callus tissues (200 mg) were transferred to MS supplemented with different concentrations $(0.0,0.5,1.0$ and $2.0 \%)$ of mannitol in the presence of 2, 4-D (2.0 mg/l) and $\mathrm{Kn}(0.5 \mathrm{mg} / \mathrm{l})$.

Fig. 5 showed that growth rate values increased in a direct relation with mannitol concentrations from the first week to the third week. On the other hand, at $2 \%$ mannitol, growth rate decrease was occurred (Fig. 5). The highest growth rate was recorded in medium containing $1 \%$ mannitol (97.14 mg/day).

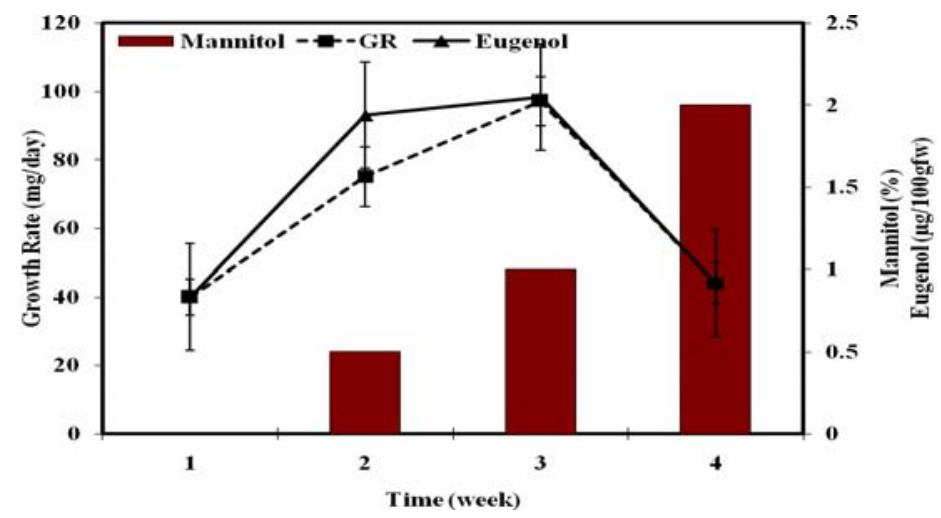

Fig. 5. Effect of different concentrations of mannitol on growth rate and eugenol content of Dianthus caryophyllus callus cultured on MS supplemented with $2.0 \mathrm{mg} / 1$ 2,4-D and $0.5 \mathrm{mg} / \mathrm{Kn}$. Values are the mean of 3 replicates $\pm \mathrm{Sd}$. 
For eugenol content, data presented in Fig. 5 showed that the highest amount of eugenol $(18.0 \mu \mathrm{g} / 100 \mathrm{~g}$ calli) was detected in medium containing $0.5 \%$ mannitol followed by $1.13 \mu \mathrm{g} / 100 \mathrm{~g}$ calli with $1 \%$ mannitol concentration. It was found that $1 \%$ mannitol concentrations caused a significant decrease in eugenol content and totally omitted in medium containing $2 \%$ mannitol.

Mannitol is a polyol normally synthesized in numerous species of vascular plants, which serves as an alternate metabolic reserve as well as an osmoticum. Mannitol accumulation increases when plants are exposed to a low water potential and the most obvious function of this compound is in osmotic adjustment (Abebe et al. 2003). Therefore, mannitol has been proposed to enhance tolerance to water deficit stress primarily through osmotic adjustment (Loester et al. 1992). many authors evaluated the effect of mannitol as a water stress agent on both growth of calli and biosynthesis of secondary metabolites. The reduction in water content caused a decrease in cell turgor pressure and consequently reduction in callus growth as expressed as callus fresh weight (AL-Taha 2013). Mohamed and Ibrahim (2012) suggested that mannitol is taken up and metabolized by plants. The in vitro growth medium contains a source of carbon, but increasing the carbohydrate concentration in the growth medium up to a limit, increases the water potential, resulting in reduced water uptake and thus caused growth inhibition. Data presented here support the results of Hadi et al. (2014) who studied the effect of mannitol on callus growth of Ruta graveolens. They found that increasing mannitol concentration caused a progressive reduction in callus fresh weight. Likewise the current experiment demonstrated that by raising mannitol concentrations to $2 \%$ the growth rate was diminished.

Of the two elicitors, mannitol seems to be more effective in enhancement and accumulation of eugenol content.

\section{Acknowledgment}

The authors sincerely thank the authority of National Research Centre (NRC) Egypt for financial support through the in home project No. 10070206 .

\section{References}

Abebe T, Guenzi AC, Martin B and Cushman JC (2003) Tolerance of mannitol accumulating transgenic wheat to water stress and salinity. Plant Physiol. 131: 17481755.

Aerts RJ, Schafer A, Hesse M, Baumann TW and Slusarenko A (1996) Signalling molecules and the synthesis of alkaloids in Catharanthus roseus seedlings. Phytochem. 42: 417-422.

Allardice P (1993) A - Z of companion planting. Angus and Robertson, Pymble. 208. 
AL-Taha HAK (2013) Effect of shock and gradual drought by PEG on callus growth and proline accumulation in sour orange (Citrus aurantium). Adv. Agric. Bot. Int. J. Bio. Soc. 5(2): 77- 83 .

Basra AS (2000) Plant growth regulators in agriculture and horticulture: Their role and commercial uses. Harworth Press, Philadelphia. 264 p.

Bown D (1995) Encyclopaedia of herbs and their uses. Dorling Kindersley, London, 424 pp.

Buiatti M, Scala A, Bettini P, Nascari G, Morpurgo R, Bogani P, Pellegrini G, Gimelli F and Venturo $\mathbf{R}$ (1985) Correlations between in vivo resistance to Fusarium and in vitro response to fungal elicitors and toxic substances in carnation. Theor. Appl. Genet. 70: 42-47.

Burfield T and Reekie SL (2005) Mosquitoes, malaria and essential oils. Intern J Aromather. 15: 30-41.

Chevallier A (1996) The encyclopedia of medicinal plants. Dorling Kindersley, London, 336 pp.

Chopra RN, Nayar SL and Chopra IC (1986) Glossary of Indian medicinal plants. (Including the supplement). Council Scientific Industrial Research, New Delhi. 330 pp.

Clery R, Owen NE, Chambers FS and Thorton-Wood SP (1999) An investigation into the scent of carnations. J. Essent. Oil Res. 11: 355-359.

Cosio EG, Frey T, Verduyn R, van Boom J and Ebel J (1990) High-affinity binding of a synthetic heptaglucoside and fungal glucan phytoalexin elicitors to soybean membranes, FEBS Lett. 271: 223-226.

Crowe JH, Hoekstra FA and Crowe LM (1992) Anhydrobiosis. Annu. Rev. Plant Physiol. 54: 579-599.

El-Ghorab AH, Mahgoub MH and Bekheta M (2006) Effect of some bioregulators on the chemical composition of essential oil and its antioxidant activity of Egyptian carnation ( Dianthus caryophyllus L.). J. Essent. Oil Bear. Plants 9(3): 214-222.

Esmaiel NN, Al-Doss AA and Barakat MN (2013) An Assessment of in vitro culture and plant regeneration from leaf base explants in carnation (Dianthus caryophyllus L.). J. Food, Agric. and Environ. 11: 1113-1117.

Galeotti F, Barile E, Curir P, Dolci M and Lanzotti V (2008) Flavonoids from carnation (Dianthus caryophyllus) and their antifungal activity. Phytochem. Lett. 1: 44-48.

Gamborg OL and Shyluk JP (1981) Nutrition, media and characteristics of plant cell and tissue cultures. In: Plant Tissue Culture : Methods and Applications in Agriculture ". by Thorp, T. A. (Ed.). PP. 21-44, Academic Press, New York.

Gobbo-Neto L and Lopes NP (2007) Plant as medicinais : Fatores de influência no conteúdo de metabólitos secundários. Quim Nova. 30(2): 374-381.

Griga MC and Klenoticova H (1994) Plant regeneration in callus cultures of faba bean (Vicia faba L.). Rostlinna Vrroba. 8: 697-702.

Guenther E (1961) The essential oils, Van Nostrand Comp. Inc., New York, U.S.A. 
Gundlach H, Muller MJ, Kutchan MJ and Zenk MH (1993) Jasmonic acid is a signal transducer in elicitor-induced plant cell cultures. Proc. Natl. Acad. Sci. U.S.A. 89: 2389-2393.

Hadi SM, Ibrahim KM and Yousif SI (2014) Effect of shock and elevated levels of mannitol on callus growth, regeneration and proline accumulation in Ruta graveolens cultures. Int. J. Curr. Microbiol. App. Sci. 3(11): 479-488.

Jurgens A, Witt T and Gottsberger G (2003) Flower scent com position in Dianthus and Saponaria species. Biochemical Sytematics and Ecology 31: 345-357.

Ketchum REB, Gibson DM, Croteau RB and Shuler ML (1999) The kinetics of taxoid accumulation in cell suspension cultures of Taxus following elicitation with methyl jasmonate, Biotechnol. Bioeng. 62: 97-105.

Kim HJ, Chen F, Wang X and Rajapakse NC (2006) Effect of methyl jasmonate on secondary metabolites of sweet basil (Ocimum basilicum L.). J. Agric. Food Chem. 22; 54(6): 2327-32.

Laiu DF and Boll WG (1970) Callus and cell suspension cultures of bush bean (Phaseouls vulgaris). Can. J. Bot. 48: 1119.

Lima HRP, Kaplan MAC and Cruz AVM (2003) Influência dos fatores abióticos na produção e variabilidade de terpenóides em plantas. Floresta ambient. 10(2): 71-77.

Loester WH, Tyson RH, Everard JD, Redgwell RJ and Bieleski RL (1992) Mannitol synthesis in higher plants: evidence for the role and characterization of a NADPHdependent mannose-6-phosphate reductase. Plant Physiol. 98: 1396- 1402.

Lu CY, Nugent G, Wardley-Richardson T, Chandler SF, Young R and Dalling MJ (1991) Agrobacterium-mediated transformation of carnation (Dianthus caryophyllus L.). Bio. Technol. 9: 864-868.

Matkowski A (2008) Plant in vitro culture for the production of antioxidants:a review. Biotechnol Adv. 26: 548-560.

Mohamed MA and Ibrahim TA (2012) Enhanced in vitro production of Ruta graveolens L. coumarins and rutin by mannitol and ventilation. Plant Cell Tiss. Org. Cult. 111: 335 343.

Mahmoud SS and Croteau RB (2002) Strategies for transgenic manipulation of monoterpene biosynthesis in plants - Review. Trends Plant Sci. 7(8): 366-373.

Mantell SH and Smith H (Eds.) (1989) In: Plant Biotechnology. Cambridge University Press, Cambridge Series. 18: 75.

Menke FL, Parchmann S, Mueller MJ, Kijne JW and Memelink J (1999) Involvement of the octadecanoid pathway and protein phosphorylation in fungal elicitor-induced expression of terpenoid indole alkaloid biosynthelic gene in Catharanthus roseus. Plant Physiol. 119: 1289-1296.

Mii M, Buiatti M and Gimeli F (1990) Carnation. In: Ammirato PV, Evans DA, Sharp WR, Bajaj YPS (eds) Handbook of plant cell culture, vol. 5. Ornamental species. McGrawHill, New York, pp. 284-318.

Miller RM, Kaul V, Hutchinson JF, Maheswaran G and Richards D (1991) Shoot regeneration from fragmented flower buds of carnation (Dianthus caryophyllus). Ann. Bot. 68: 563-568. 
Mizukami H, Tavira Y and Ellis BE (1993) Methyl jasmonate-induced rosmarinic acid biosynthesis in Lithospermum erythrorhizon cell suspension cultures, Plant Cell Rep. 12: 706-709.

Nade1 BL, Altman A and Ziv M (1989) Regulation of somatic embryo- genesis in celery cell suspensions. Plant Cell Tiss. Org. Cult. 18: 181-189.

Nugent G, Wardley-Richardson T and Lu CY (1991) Plant regeneration from stem and petal of carnation (Dianthus caryophyllus L.). Plant Cell Rep. 10: 477-480.

Ortuño A, Oncina R, Botia JM and Del Rio JA (1999) Regulation of diosgenin expression in Trigonella foenum-graeco plants by different plant growth regulators. Food Chem. 65: 227-232.

Palet A, Ribas-Carbo M, Argiles JM and Azcon-Bieto J (1991) Short-term effects of carbon dioxide on carnation callus cell respiration. Plant Physiol. 96: 467-472.

Phillips GC (2004) In vitro morphogenesis in plants - Recent advances. In Vitro Cell Dev. Biol. Plant. 40: 342-345.

Povh JA and Ono EO (2006) Rendimento do óleo essencial de Salvia officinalis L.sob ação de reguladores vegetais. Acta Sci. Biol. Sci. 28(3): 189-193.

Rao YS, Mathew KM, Kumar KP, Salykutty J, Laxmanan R, Madhusoodanan KJ, Potty SN, Joesph S, Edison S, Raman KV, Sasikumar B, Babu KN and Eapen SJ (1997) Tissue culture studies on tree spices. Biotechnology of spices, medicinal and aromatic plants. Proceedings of the national seminar on biotechnology of spices and aromatic plants. Calicut, India, 39-44.

Rebecca M and Deepa SP (2012) Effect of methyl jasmonate and chitosan on growth characteristics of Ocimum basilicum L., Ocimum sanctum L. and Ocimum gratissimum L. cell suspension cultures. African Journal of Biotechnology 11(21): 4759-4766.

Saenz-Carbonell L and Loyola-Vargas VM (1996) Elicitation of tropane alkaloid biosynthesis in transformed root cultures of Datura stramonium. Appl. Biochem. Biotechnol. 61: 321.

Sangwan NS, Farooqi AHA, Shabih F and Sangwan RS (2001) Regulation of essential oil production in plants. Plant Growth Regul. 34: 03-21.

Saran S, Menon S, Shailajan S and Pokharna P (2013) Validated RP-HPLC method to estimate eugenol from commercial formulations like Caturjata churna, Lavangadi vati, Jatiphaladi, Sitopaladi churna and clove oil. Journal of Pharmacy Research 6: 53-60

Silva AS (2002) Análise técnica econômica e de tendências da indústriabrasileira de óleos essenciais. Papel Virtual, Rio de Janeiro. 202 p.

Shen B, Jensen RG and Bohnert HJ (1997) Increased resistance to oxidative stress in transgenic plants by targeting mannitol biosynthesis to chloroplasts. Plant Physiol. 113: $1177-1183$.

Smirnoff N and Cumbes QJ (1989) Hydroxyl radical scavenging activity of compatible solutes, Phytochem. 28: 1057- 1060.

Snedecor CW and Cochran WC (1980) Statistical Methods, Iowa State University Press, Ames, I.A., pp 507.

Sparnaaij L (1987) Third Int. Symp. carnation culture. Acta Hortic. 216, Int. Soc. Hortic. Sci, Wageningen. 
Szoke E, Kuzovkia NI, Versar-Petri G and Smirnov AM (1979) The effect of growth regulators on biomass formation in callus cultures of Matricaria chamomilla. L. Herba Hung. 18: 41-57.

Thimann KV, Loos GM and Samuel EW (1960) Penetration of mannitol into potato discs. Plant Physiol. 35: 848-853.

Uphof JCT (1968) Dictionary of Economic Plants, 2nd edn., Cramer, Lehre, 591 pp.

William A, John G and Hendel J (1996) Reversed-phase high-performance liquid chromatographic determination of ginsenosides of Panax quinquefolium, J. Chromatogr. 775: 11-17.

Yuri JA (1988) Anwendung von polyethylen-glycol und mannitol bei studien zum wasserstre8. Gartenbauwissenshaft. 53: 270-273

Zhang $\mathbf{H}$ and Memelink J (2009) Regulation of secondary metabolism by jasmonate hormones. In: Plant-derived Natural Products Synthesis, Function, and Application, Osbourn A E and Lanzotii V. (eds). pp. 181-194. Springer Science - Business Media, LCC.

Zhao J, Davis LC and Verpoorte R (2005) Elicitor signal transduction leading to production of plant secondary metabolites. Biotechnol. Adv. 23: 283-233.

Zhao J, Zhu WH, Hu Q and Guo YQ (2001) Elicitor-induced indole alkaloid biosynthesis in Catharanthus roseus cell cultures is related to $\mathrm{Ca}^{2+}$ influx and the oxidative burst, Plant Sci. 161: 423-431.

Zuker A, Tzfira T, Ben-Meir H, Ovadis M, Shklarman E, Itzhaki H, Forkmann G, Martens S, Neta-Sharir I, Weiss D and Vainstein A (2002) Modification of flower color and fragrance by antisense suppression of the flavanone 3-hydroxylase gene. Molecular Breeding 9: 33-41. 